\title{
Disaster-based participatory development planning
}

\author{
Benny Hidayat ${ }^{1 *}$, and Anggraini Rasadi $^{2}$ \\ ${ }^{1}$ Civil Engineering Department, University of Andalas, Indonesia \\ ${ }^{2}$ Student of the Master Program in Civil Engineering, University of Andalas, Indonesia
}

\begin{abstract}
Disasters are a global problem in many countries. Particularly in Indonesia,where has many prone areas to disasters. The perspective of disastermanagement has entered a new paradigm, from previously only focusing onemergency response activities to mitigation and preparedness approaches. Mitigation andpreparedness are carried out when disasters do not occur. Indisaster risk mitigation, it is necessary to involve active communityparticipation, especially in planning for disaster-related development. So far, the communities are mostly only passive object in the development program that only accepts any initiatives of disaster-based development made by thegovernment. The communities need to be placed as active subjectsparticipating in the disaster-related development in their community. Many disaster-based infrastructure developments so far still use the top-downmechanism, namely disaster planning, and management entirely based on the initiation of the government or organization. In Disaster Management Law No.24/2007, it is stated that the community has the right to be actively involved indisaster management efforts in their communities. This paper aims to identifywhat forms of community participation in disaster-based development,especially at the planning stage of infrastructure development activities.
\end{abstract}

\section{Preliminary}

Community participation in disaster-based development planning is necessary especially when identifying risks that exist in their local community. The vulnerablecitizen are more aware of the environmental conditions based on their experience and knowledge on disasters that have occurred in their territory. Citizen participation in the planning process is expected to make disaster risk reduction will be based on local wisdom and traditional knowledge applies on their community.

\section{Literature}

\subsection{Disaster}

\subsubsection{Definition}

Indonesian Disaster Law No.24/2007 or UU No.24/2007 decribed Disaster as an event or series of events that threaten and disrupt the lives and livelihood caused by both natural factors and/or non-natural or human factors resulting in the emergence of human lives, environmental damage, loss of property, and the psychological impact.

Disaster is a meeting of three elements: hazard, vulnerability, and abilities that trigger by an event. The relationship of these three elements can be seen in the following equation (1):

Risk $=\mathrm{f}($ Hazard $\mathrm{x}$ Vulnerability / capability) (1)
The disaster risks directly proportioned with the hazards and vulnerabilty. Disaster risk can be reduced by increasing the ability of society and by reducing the vulnerability of communities-affected to disasters.

\subsubsection{Disaster Mitigation Cycle}

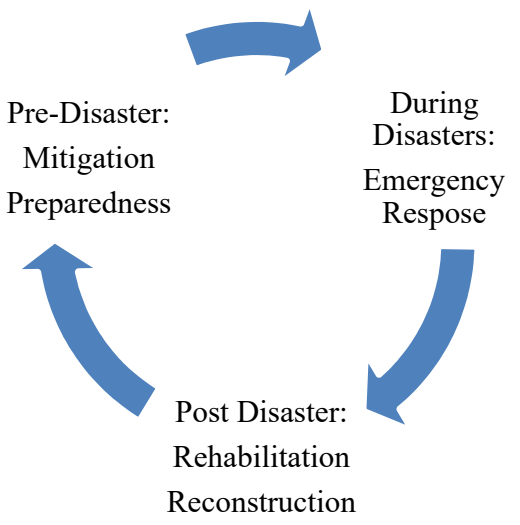

Fig 1. Disaster Mitigation Cycle

Disaster Mitigaton is a series of efforts that prevents disaster. Disaster Mitigation scheme including Disaster Management Policies, Disaster Prevention Activities, Emergency Response and Rehabilitation (UU No. 24, 2007). Disaster Mitigastion is basically organized in a this following cycle:

1. Pre-disaster, which include:

a. When disaster strikes photo

b. The situation there is a potential disaster

\footnotetext{
* Corresponding author: bennyhidayat@eng.unand.ac.id
} 
2. Emergency Response

3. Post Disaster

\subsection{Community Based Disaster Management}

Mitigation is a series of efforts made to reduce disaster risk, either through physical development or by increasing citizen awareness and increasing community capacity to deal with disasters (UU No. 24, 2007). The Yokohama Strategy (1994) explained that the disaster risk reduction strategy should be systematically integrated with Development policies and planning.

Disaster Mitigation can be classified into two forms: Non-Structural and Structural mitigation. Non-Strucural Mitigation are regulations, counseling, and Disaster awareness Education. The Structural Mitigation is in the form of buildings and infrastructure. Disaster-based infrastructures built to prevent, securing, and reduce the impact caused by disasters. Disaster-based infrastructures such as dikes, dams, breakwater, earthquake-resistant buildings, etc (Perka BNPB, 2008).

Community participation is important in Disasterbased development planning. UU No. 24/ 2007 stated that citizen has the rights to participate in decisionmaking on disaster management activities, particularly in their local community. Citizen can participate in the disaster mitigation planningin order to reduce disaster risks. The disaster mitigation planning is being made on the pre-disaster stage.

\subsection{Participatory Development Planning}

\subsubsection{Concept of Participatory Development Planning}

Planning can be simply described as an activity made for a future better by considering the circumstances in the present as well as the circumstances in the past. Development planning is the process of formulating alternatives or decisions based on the data or facts that will be used as a material for carrying out a series of activities / activity of society both physical in order to achieve a better purpose (Maripah, 2017). Participatory development planning is a form of planning that involve the community actively ranging from problem identification, formulation of the problem, the search for alternative solutions to problems.

\subsubsection{Participation Rate}

Arnstein (1969) revealed eight levels of participation that illustrates the citizen's authority and role in the community's decision-making. Arnstein describes eight levels of community participation as presented in Table 1. The eight levels of participation are subdivided into three general pattern which are non-participation, tokenism, and Citizen Power.

Table 1.Levels of Citizen Participation according to Participation Ladder Arnstein

\begin{tabular}{|c|c|c|c|}
\hline & $\begin{array}{c}\text { STAGE OF } \\
\text { PARTICIPATION }\end{array}$ & CHARACTERISTICS & $\begin{array}{l}\text { PATTERN PHASES } \\
\text { PARTICIPATION }\end{array}$ \\
\hline 1. & Manipulation & $\begin{array}{l}\text { - The community is only being used as a vehicle to achieve } \\
\text { the goal made by government. } \\
\text { Government socializing/community meetings just to give } \\
\text { a brief knowledge about the program or to engineering } \\
\text { public support for the program. } \\
\text { - Governments are actively educated, persuaded, and } \\
\text { advised the citizen, not the reverse. }\end{array}$ & \multirow[t]{2}{*}{ Non-Participation } \\
\hline 2. & Therapy & $\begin{array}{l}\text { - The community is being involved in many activities.But } \\
\text { masquerading as citizen participation, the actual goal is } \\
\text { simply to weaken the control/power of society. }\end{array}$ & \\
\hline 3. & Informing & $\begin{array}{l}\text { - The public being informed about their rights and } \\
\text { responsibilities and options. However, the information is } \\
\text { only one direction, from the government only and there is } \\
\text { no feedback from the community. Society does not have } \\
\text { the authority to negotiate with the government. } \\
\text { The most frequent tools used aresuch as news media, } \\
\text { pamphlets, posters, and Responses to Inquiries }\end{array}$ & \multirow{3}{*}{ Tokenism } \\
\hline 4. & Consultation & $\begin{array}{l}\text { - Encouragingcitizen to express their concerns and ideas, } \\
\text { but there is no guarantee that their opinion will be taken } \\
\text { into account. } \\
\text { The frequent methods used for consultation level are } \\
\text { attitude surveys, neighborhood meetings, and public } \\
\text { hearings. } \\
\text { The government uses the consultation process as evidence } \\
\text { that the decision-making process has been based on } \\
\text { procedures of participatory planning. }\end{array}$ & \\
\hline 5. & Placation & - Citizen begin to have an impact, although tokenism is still & \\
\hline
\end{tabular}




\begin{tabular}{|c|c|c|c|}
\hline & & $\begin{array}{l}\text { - The government allow community to advice and } \\
\text { participate in the planning process but retain their right to } \\
\text { judge the legitimacy and feasibility of the advice. } \\
\text { The degree of Placation depending on the quality of } \\
\text { technical assistance that the community have in } \\
\text { articulating their priorities and the extent to which the } \\
\text { citizen has been organized to press for those priorities. } \\
\text { citizens are extensively involved in planning, but do not } \\
\text { get benefits beyond the extent the powerholders decide to } \\
\text { placate them. } \\
\text { Citizen does not have a great influence on decision } \\
\text { making. } \\
\text { Citizen are given the opportunity to plan activities but } \\
\text { they do not have adequate time period and adequate } \\
\text { technical assistance so that people are not able to do much } \\
\text { in the implementation of the program. } \\
\text { Little or no guarantee of the suggestions from the } \\
\text { community will continued during the stage of } \\
\text { implementation. }\end{array}$ & \\
\hline 6. & Partnership & $\begin{array}{l}\text { - The authority is based on negotiations between the } \\
\text { government and the public. The government agree to share } \\
\text { planning and decision-making responsibilities through such } \\
\text { structures as joint policy boards, planning committees and } \\
\text { mechanisms for resolving impasses. } \\
\text { Although the government has veto power in deciding and } \\
\text { making decisions, the government is still considering the } \\
\text { aspirations of the people. } \\
\text { The community are already independent and being able to } \\
\text { hired the required technical personnel. Leadership of the } \\
\text { group leader has also been accountable so that the strength } \\
\text { of the community, can affect the outcome of the planning. } \\
\text { Both sides benefited. }\end{array}$ & \multirow[t]{3}{*}{ People Power } \\
\hline 7. & Delegated Power & $\begin{array}{l}\text { - Citizen has dominant power in decision-making over a } \\
\text { particular plan or program. } \\
\text { Society has more representatives in the committee than the } \\
\text { government's representatives }\end{array}$ & \\
\hline 8. & Citizen Control & $\begin{array}{l}\text { - The community has full authority in a program. Be in full } \\
\text { charge of policy and managerial aspects, and be able to } \\
\text { negotiate the conditions under which "outsiders" may } \\
\text { change them. }\end{array}$ & \\
\hline
\end{tabular}

In general the pattern of non-participation, the government only informs the public about a program but do not make room for the public to participate in planning and implementation of the program. This pattern is sometimes used by the authorities to replace the genuine participation. Manipulation Level and Therapeutic level are part of this pattern.

The next pattern is, the pattern of tokenism slightly better than the pattern of non-participation. On the pattern of tokenism, citizen are begin to be heard even if their aspirations are not all accommodated by the government. Society does not have the certainty that what they are proposing will be followed by the government. Levels of participation into this pattern is the Informing Level, Consultation level, and Placation Level.

The last pattern is the pattern of Citizen Power, where people have a greater authority than the government in planning and decision making in a program. Levels of participation into this pattern is the level of the Partnership, the level of Delegation of Powers, and the level of Community Control.

\section{Methodology}

This study was conducted using qualitative descriptive study is to disclose events or facts, circumstances, phenomena, variables and circumstances that occur as the research proceeds (Prasetyo, 2016). Data were obtained through analyzing the journals of community involvement in development programs of disaster. Results of research and analysis in the form of tables that describe the level of community participation in development planning based on disaster.

\section{Results and Discussion}

From the results of the collection of literature sources obtained eight journals that discuss examples of community participation in development planning based on disaster. Levels of community participation in the planning of disaster-driven development can be seen in the following table: 
Table 2. Levels of Citizen Participation in Disasater-Based Development Planning

\begin{tabular}{|c|c|c|c|c|}
\hline No. & Project & Literature & $\begin{array}{c}\text { Level of } \\
\text { participation }\end{array}$ & Description \\
\hline 1. & $\begin{array}{l}\text { Regional Planning Post } \\
\text { Disaster Coast } \\
\text { Tourism }\end{array}$ & Istiyanto (2011) & Consultation & $\begin{array}{l}\text { Residents directly submit complaints and feedback } \\
\text { about disaster management infrastructure. } \\
\text { Unfortunately, this process only to the stage of } \\
\text { proposals and feedback alone does not continue on } \\
\text { the next stage. }\end{array}$ \\
\hline 2. & $\begin{array}{l}\text { Community Relocation } \\
\text { Program eruption of } \\
\text { Mount Merapi Disaster } \\
\text { Victims }\end{array}$ & Bawole (2015) & partnerships & $\begin{array}{l}\text { The community is involved, from planning to the } \\
\text { implementation of the development. People are also } \\
\text { accompanied intensively by facilitators and experts. }\end{array}$ \\
\hline 3. & $\begin{array}{l}\text { Reconstruction of } \\
\text { Teluk Dalam City Post } \\
\text { Earthquake and } \\
\text { Tsunami Disaster }\end{array}$ & Sukawi (2010) & Placation & $\begin{array}{l}\text { People are given an understanding of City Spatial } \\
\text { Plan and can not give suggestions on city planning. } \\
\text { People are given the opportunity to provide input } \\
\text { and will be followed up sebulum-setting } \\
\text { regulations. }\end{array}$ \\
\hline 4. & $\begin{array}{l}\text { Prone Area } \\
\text { Development } \\
\text { Village III Mount } \\
\text { Merapi disaster } \\
\text { Mranggen } \\
\end{array}$ & Susanti (2016) & Manipulation & $\begin{array}{l}\text { Only the device including the village head and } \\
\text { village heads and community leaders involved in } \\
\text { planning disaster mitigation activities. }\end{array}$ \\
\hline 5. & \begin{tabular}{lr}
\multicolumn{2}{l}{ Community-based } \\
Disaster & Risk \\
Reduction in Sub & Salam, Magelang
\end{tabular} & $\begin{array}{l}\text { Hendarsah } \\
(2012)\end{array}$ & partnerships & $\begin{array}{l}\text { The community is involved in identifying potential } \\
\text { risks for local communities more aware of the } \\
\text { characteristics and potential hazards in their area. } \\
\text { The results with the community participatory risk } \\
\text { identification is used for further analysis. }\end{array}$ \\
\hline 6. & $\begin{array}{lr}\text { Program } & \text { for } \\
\text { Community } & \text { Based } \\
\text { Disaster } & \text { Risk } \\
\text { Reduction (PRBBK) in } \\
\text { Bitung }\end{array}$ & $\begin{array}{l}\text { Kalangkahan } \\
\text { (2016) }\end{array}$ & Manipulation & $\begin{array}{l}\text { People are not involved directly in the discussion } \\
\text { PRBBK program but only the government officials } \\
\text { of the city, district, village, Head of Environment } \\
\text { and Chairman of RT. Society simply implement the } \\
\text { decisions agreed upon by government officials. }\end{array}$ \\
\hline 7. & $\begin{array}{l}\text { Disaster Resilient } \\
\text { Programs in Teluk } \\
\text { Bakau Village Bintan } \\
\text { District }\end{array}$ & Noza, N (2018) & partnerships & $\begin{array}{l}\text { BPBD Riau Island Province encourage and } \\
\text { facilitate communities to plan and implement } \\
\text { programs for Disaster Resilient Village. Engage } \\
\text { community planning maps and vulnerability } \\
\text { analysis as well as the draft of the village disaster } \\
\text { management plans. }\end{array}$ \\
\hline 8. & $\begin{array}{l}\text { Mount Merapi Disaster } \\
\text { Mitigation Program }\end{array}$ & Triyana (2011) & Manipulation & $\begin{array}{l}\text { People claim that they are less involved in disaster } \\
\text { management. }\end{array}$ \\
\hline
\end{tabular}

The level of community participation in development planning based disaster in Indonesia are generally located on the level of manipulation, Consulting, Penentraman, and Partnership.

\section{a. Manipulation level}

Manipulation level into the pattern of non-participation in which people are not given space to participate. Manipulation on participation levels, people are still used as objects of development where people just accept programs that have been planned and set by the government. As happened in Community Based Disaster Reduction Program (PRBBK) in Bitung is positioning communities as recipients of the decision and "directed" to carry out the planned program (Kalangkahan, 2016). People are not involved in the decision making process for decision-making is only represented by government officials only such Lurah, Head of Environment and Chairman of RT. Socialization program should reach vulnerable populations to disasters and not just on the village government officials only. The same thing happened in the village planning mitigation Mranggen that only by certain people such as village heads and the device is the head of the hamlet and community leaders (Susanti, 2016). Society can not be involved in active voice input and suggestions regarding structural mitigation planning in their area.

At the Disaster Management Program Eruption of volcano located in Sleman and Magelang. Citizens around the volcano wants to be involved in disaster relief even though they do not know what kind of participation they have to do (Triyana, 2011). This shows that the government is less encouraging community participation in disaster management and have not been up in educating people about the space of participation that can be followed by the public, especially in disasterbased development planning. 


\section{b. Consultation Level}

Citizen participation at the level of consultations characterized by their people the chance to submit comments and suggestions in the development plan although there is no guarantee that what is proposed by the community will be included in planning documents, as occurs in the regional development planning Tourism Parangtritis aftermath of the earthquake and tsunami 2006. In the process of designing the redevelopment project area beach tourism, involvement of local communities to provide input. However, community involvement was limited to proposing only and no followup.

\section{c. Placation Level}

At Placation level, people a little more involved in the planning process itself not only make suggestions. Sukawi (2010) describes in Urban Planning Teluk Dalam, the people involved in public consultations and participate formulate infrastructure development priorities. In addition, people also give advice and information about potential problems that are very useful in planning the rebuilding the city.

\section{d. Partnership Level}

The highest levels of community participation in development planning based disaster is the level of partnership in which the government together with the community-based development planning disaster. For example in Disaster Mitigation Planning District Salam, Magelang regency, the Government consults with local communities in a Focus Group Discussion (FGD). FGD aims to identify the characteristics of the threat and vulnerability to disasters. Local communities are the first to deal with disaster risks that need to involve community participation in planning disaster-driven development (Hendarsah, 2012).

Another with participatory development planning at Community-Based Settlement Relocation Program for victims of natural disasters Merapi eruption. The relocation program involving communities in planning for both the relocation site selection, site plan, to manufacture Detail Engineering Design (DED). Not only that, the government increased the capacity of the community by providing intensive assistance to community facilitators and experts. People are given the strengthening of the fundamentals of development planning as insightful knowledge on sustainable ecological settlements, aspects relating to the Basic Building Coefficient, Coefficient of Building Floor Area as well as an understanding of disaster mitigation.

Government support was instrumental in fostering community participation. In implementing the Program for Disaster Resilient Village in Teluk Bakau, Bintan regency, supported and facilitated by BPBD of Riau Islands Province. Local authorities involving the private sector, community groups and other groups particularly vulnerable communities to disasters, disaster management appropriate to the situation and needs of the community. The government together with the community to work together in disaster-based development planning. Planning is then realized in the form of building a breakwater to prevent coastal erosion disaster (Noza, 2018).

\section{Conclusion}

Participatory development planning should encourage people to actively engage in the process of development planning in their area. Generally disaster-based participatory development planning in Indonesia has led to patterns of Citizen Power, although still in the lowest level which is Partnership Level. People have started to be actively involved in planning mitigation structures that exist in their communities. Community participation has been seen by the public ikutnya submit suggestions and feedback regarding development planning, follow formulate priorities and participate in the planning of the DED. Although based participatory development planning disaster in Indonesia has shown a positive trend, but still there is the practice of manipulation in which community participation was "directed" and moved to the program that has been set by the government. The government is expected to continue to encourage community participation by giving wide space to be involved in the development planning process. Governments also need to provide intensive technical assistance to communities to increase the capacity of community-based development planning in the field of disaster.

This research is part of Penelitian Tesis Magister (PTM)/ Magister Thesis Research. Thanks to Kemenristekdikti and LP3M Andalas University for funding this research (contract number T/34/UN/16/17/PT.01.03/PKR-Kebencanaan/2019).

\section{References}

1. Arnstein, S (1969). JAIP 35 (4) 216-224. (1969)

2. Bawole, P., Jurnal Tesa Arsitektur 13 (2) (2015) http://journal.unika.ac.id/index.php/tesa/article/vie $\mathrm{w} / 644$

3. BNPB (2008). Peraturan Kepala Badan Nasional Penanggulangan Bencana No. 4 tentang Pedoman Penyusunan Rencana Penanggulangan Bencana. Jakarta (2008)

4. Hendarsah, H. (2012). Sosiokonsepsia 17 (03) (2012).

https://puslit.kemsos.go.id/upload/post/files/450bf2 cac163e2f5046896b541bfe36d.pdf

5. Istiyanto, B. Jurnal Ilmu Komunikasi 9 (I) 16-27. (2011)

http://repository.upnyk.ac.id/1748/

6. Kalangkahan, P., J. Ilmiah Society 1 (24) (2016) https://ejournal.unsrat.ac.id/index.php/jurnalilmiahs ociety/article/view/16862

7. Maripah., Jom FISIP 4 (2) (2017). https://jom.unri.ac.id/index.php/JOMFSIP/article/vi ew/15651 
8. Noza, N. Partisipasi Masyarakat dalam Program Desa Tangguh Bencana di Desa Teluk Bakau Kabupaten Bintan. P1 (1). 1-15. ISSN110565201149. (2018)

http://repository.umrah.ac.id/id/eprint/412/

9. Nurcholis, H. Perencanaan Partisipatif Pemerintah Daerah. Jakarta: Garsindo. (2009)

10. Pemerintah Indonesia. Undang Undang Republik Indonesia No. 24 Tahun 2007 tentang Penanggulangan Bencana. Lembaran RI Tahun 2007 No. 66. Sekretariat Negara. Jakarta. (2017)

11. Prasetyo, A. Pengertian Penelitian Deskriptif Kualitatif(2016)https://www.linguistikid.com/2016/ 09/pengertian-penelitian-deskriptifkualitatif.html?m=1 diakses pada 06 Oktober 2019.

12. Sukawi., Local Wisdom 2 (2) 01-08. (2010). http://jurnal.unmer.ac.id/index.php/lw/article/down load/1374/879
13. Susanti, E \& Khotimah, N., Geomedia 14 (1) (2016)

https://journal.uny.ac.id/index.php/geomedia/articl e/view/13778

14. Triyana, H. J \& Wibowo, R. A., Mimbar Hukum Edisi Khusus, November, 1-237. (2011) https://jurnal.ugm.ac.id/jmh/article/download/1616 $7 / 10713$

15. Twigg, J. Disaster Risk Reduction: mitigation and preparedness in development and emergency programming. Humanitarian Practice Network, London. (2004)

https://www.ifrc.org/PageFiles/95743/B.a.05.\%20

Disaster\%20risk\%20reduction_\%20Good\%20Pract ice\%20Review_HPN.pdf

16. Yokohama Strategy and Plan of Action for a Safer World. Guidelines for Natural Disaster Prevention, Preparedness and Mitigation. (1994) 